\title{
The 1997-1998 Umbria-Marche post-earthquakes investigation: perspective from a decade of analyses and debates on the surface fractures
}

\author{
Francesca R. Cinti \\ Istituto Nazionale di Geofisica e Vulcanologia, Roma, Italy
}

\begin{abstract}
The Umbria-Marche sequence represents the first case in Italy for which the surface effects of a moderate seismic event $(5<M<6)$ were systematically investigated and documented. Surface fractures attributed to the events were mapped by several groups of researchers. The coseismic features were expressed mainly by NW-SE trending, discontinuous, linear open fractures, as well as fracture swarms, locally with centimetric vertical displacements. They affected rocks and loose deposits, buildings, and roads. Because of the earthquake sizes $(M \leq 6)$, the deformation was faint, making the detection difficult and giving rise to different seismotectonic interpretations: specifically, surface rupture of the seismogenic fault, triggered slip on secondary faults, and shaking-induced sliding of debris. Consequently, different models of connection between surface offsets and displacements at depth were proposed that integrated geology with other geophysical data. However, whether direct or indirect expression of the deep dislocation, the geometry of these fractures reflected the seismogenic structure. Even in the case of these moderate-earthquakes features, geomorphical and paleoseismological studies provide data for reconstructing the recent tectonic evolution of the region and for determining the frequency and size of earthquakes. Finally, we learned a more efficient way to prepare for post-earthquake emergency response, particularly for long-lasting sequences in highly vulnerable built environments, such as the ancient villages within the Apennines.
\end{abstract}

Key words Umbria-Marche seismic sequence - coseismic surface fractures - moderate size earthquakes - post-earthquake emergency response

\section{Introduction}

The 1997-1998 Umbria-Marche seismic sequence was composed of three $5.5<\mathrm{M}<6$ main events (occurring at 00:33 and at 09:40 UTC on 26 September 1997, at 15:23 UTC on 14 Octo-

Mailing address: Dr. Francesca R. Cinti, Istituto Nazionale di Geofisica e Vulcanologia, Via di Vigna Murata 605, 00143 Roma, Italy; e-mail: cinti@ingv.it ber 1997) and three shocks around $M=5$. The sequence lasted from September 1997 to April 1998 and caused severe damage over a large area (maximum MCS intensity I=IX in some villages near the epicentral area) and loss of human lives. Many historical and artistic centers (e.g. Assisi and Foligno in Umbria) were strongly damaged. The sequence belongs to the class of the moderate earthquakes which have devastating consequences in the Apennines environment. The enormous cultural and archaeological heritage of several ancient villages and towns renders this territory one of the most hazardous and vulnerable.

Geologists may contribute to the assessment of seismic hazard through the identification of those faults showing the potential for producing 
events of magnitude around 6, which is considered the threshold of energy required for producing permanent dislocation on the earth's surface (e.g. Bonilla, 1988), either primary surface faulting, or faulting associated with the activation/reactivation of secondary faults.

The present contribution focuses on the geological investigations started few hours after the occurrence of the first mainshock of the sequence on 26 September. The Umbria-Marche sequence definitively drew the attention of geologists interested in the detection of coseismic surface deformation. I summarize the many studies developed in the ensuing years on the mapping and the analysis of the surface fracturing in and around the epicentral areas. This paper is organized in three sections: 1) the thenknowledge of geological and seismological data, 2) the seismic crisis and the collection of surface data, analysis and interpretation, and 3) the lessons learned from the experience: insights for assessing the hazard and for improving post-earthquake intervention.

\section{Our Knowledge prior September 1997}

The most recurrent consideration that the scientific community asks itself after a natural disaster is: was it somehow predictable? Obviously, there is not a positive answer to this critical question, yet certainly before this event we were not completely ignorant. In the following, I will discuss the geological and seismological knowledge at that time.

Prior to the 1997 Umbria-Marche sequence, the 1980, $M_{\mathrm{s}} 6.9$, Irpinia earthquake in southern Italy was the only high-energy event that produced permanent deformation at the surface in «modern time» and drew the interest of several geologists (Carmignani et al., 1981; Westaway and Jackson, 1987). The 1980 event marked the recognition in Italy of earthquake geology as a tool for the comprehension of the earthquake generation process.

Earthquakes of 1997-size and larger were frequent in the historical catalogue of the Umbria-Marche region, although none had been reported in the epicentral area of the 1997 shocks (fig. 1a). Among the earthquakes close to the 1997 epicentral area, the 1279 event is the only one that on the basis of its damage distribution (effects are reported both west and east of Colfiorito) could have originated on the same faults as the September 1997 shocks. However, the intensity data of this earthquake are insufficient to estimate an accurate location (Castelli et al., 1997; Boschi et al., 1998) and thus to univocally relate it to the same fault system. Instrumental crustal seismicity pre-1997 in the Umbria-Marche region included only two $M>5$ normal-faulting earthquakes (fig. 1a,b): south of the region of Colfiorito was the 1979 Norcia event $\left(M_{S} 5.8\right.$, Deschamps et al., 1984), and to the northwest was the 1984 Gubbio earthquake (M $\mathrm{M}_{\mathrm{s}} 5.3$, Haessler et al., 1988). These events occurred as single mainshocks followed by aftershocks, and the instrumental seismicity of the past 20 years in the area does not show any complex and prolonged seismic sequence as occurred in 1997 and in the eighteenth century (Chiaraluce et al., 2004).

In conclusion, both the historical and instrumental records prior to September 1997 showed that large earthquakes, at least over the past 700 years, had not affected the northernmost portion of the 1997 event area, and its southern portion for an even longer period.

Despite this lack of seismic activity, the area struck by the sequence in 1997 (fig. 1a,b) had already been investigated by several researchers involved in active tectonics studies. Several Authors had pointed out the presence of Quaternary faults in the epicentral area of the 26 September 1997 mainshocks (i.e. Calamita and Pizzi, 1993; Cello et al., 1997; Tondi et al., 1997). On the other hand, no indication for fault activity was recognized within the area where the 14 October event occurred. Cello et al. (1997) performed a pioneering structural analysis of this sector of the Apennines and determined the presence of three NS-oriented main faults with evidence of left lateral movements, and of NW-SE-trending minor faults with oblique to vertical displacements. The Colfiorito and Cesi basins, epicentral areas of the 26 September events, are bounded on the north by the NW-SE trending structures and on the east by the western- 

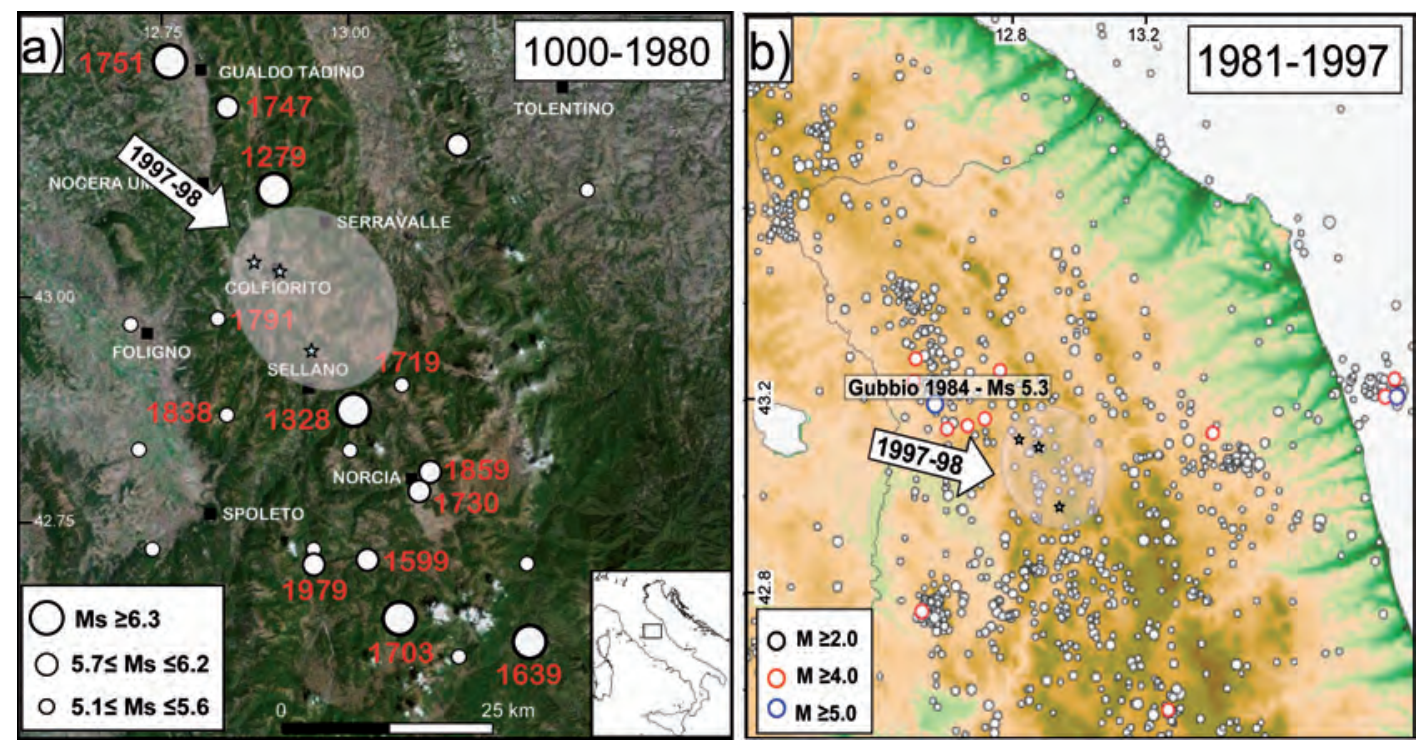

Fig. 1a,b. a) Historical and pre-1981 instrumental earthquakes (CPTI Working Group, 2004) and b) 1981-1997 instrumental seismicity (Castello et al., 2005) within and surrounding the area of the 1997-1998 seismic sequence, indicated by the shaded area (stars are the epicenters of the three mainshocks).

most fault of the main NS system. Cello et al. (1997) found that the NW-SE fault bounding the Colfiorito basin (Le Scalette Mt. fault) is exposed at the surface for about $7 \mathrm{~km}$ and that many of the basin-bordering faults have evidence of Late Pleistocene-Holocene dislocation. Most of the faults considered capable of coseismic faulting are located at the interface between bedrock and Quaternary (20-15 ka) slope deposits.

Because the historical and instrumental records indicated that the area of the 1997 sequence was part of a seismic gap at least 7 centuries long, characterized by modest and rare seismicity, the area could have been interpreted incorrectly as a relatively low energyreleasing zone. However, the geological analysis pointed to the seismogenic potential of the area. Thus, before the sequence occurred, we could not have predicted «when» an earthquake might occur, but we could have argued about «how» (i.e. rupture mechanism, source complexity), and we did know «where», based on geological-structural analyses.

\section{The field reconnaissance}

In this section I will describe the geologists' responses to the Umbria-Marche seismic crisis and summarize the data collected in the field. The seismic sequence consisted of multiple shocks, so that in the description of the facts, I will follow the timetable of the main earthquakes.

At 00:33 UTC (hereafter called «00:33») on 26 September 1997, the sequence started with a moderate size $\left(\mathrm{M}_{\mathrm{w}}\right.$ 5.7) yet damaging normalfaulting earthquake near the village of Colfiorito (figs. 2 and 3 ). This event was the beginning of a six-month long period of seismic activity (for extended seismological description, see Chiaraluce et al., 2003; 2004, and references therein). The sequence had been preceded by a $\mathrm{M}_{\mathrm{w}} 4.5$ foreshock on 3 September (fig. 2).

Early in the morning of 26 September, geologists from nearby Institutions were already in the field to document surface effects associated with the 00:33 mainshock. The team of Cello et al. (1998) searched for surface faulting features 


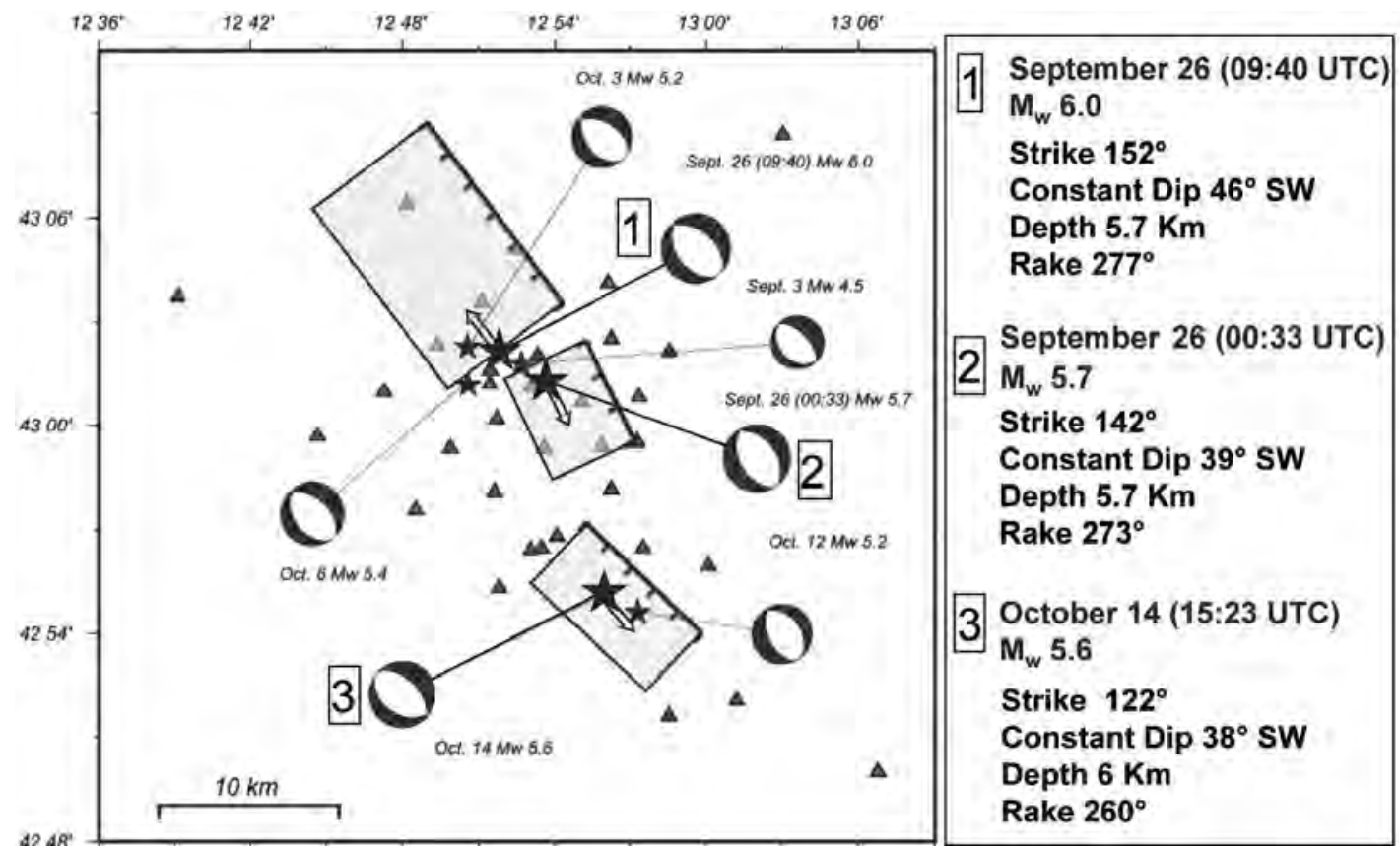

Fig. 2. Surface projections of the faults that ruptured during the three largest events (numbered, north to south) (modified by Chiaraluce et al., 2004). The fault-plane solutions of the 3 September foreshock and of the six shocks with $\mathrm{M}>5$ are shown. The distribution of the temporary seismic stations (grey triangles) is also mapped. To the right: the fault parameters for the three mainshocks according to Chiaraluce et al. (2003). The authors define shallow, gently dipping blind normal faults; the fault planes are not listric, but rather maintain a constant dip through the entire seismogenic volume.

by using as reference the map of capable faults (sensu IAEA, 1991) published in Cello et al. (1997). They started their fieldwork on the Costa-Cesi fault $\left(\sim 130 \mathrm{~N}\right.$ trending, $50^{\circ}-70^{\circ} \mathrm{SW}$ dipping, 1-3 $\mathrm{m}$ high bedrock fault scarp), that runs along the northeastern steep slope of the CostaCesi basin (see figs. 3 and 4 for location). Behind the village of Costa, features observed along fresh exposures of the bedrock fault plane (fig. 5a) suggested a dominant dip-slip motion with a minor left-lateral component. Cello et al. (1998) concluded that a maximum $8 \mathrm{~cm}$-high free-face was produced over a total length of $\sim 1$ $\mathrm{km}$ along the Costa segment.

Before going further, it is worth remarking that although sites were visited during the same period, there were conflicting opinions between different survey teams on the regularity of slip vectors (direction and size) and the linear extent of surface breaks at the Costa site, as well as at some of the other surveyed sites. In this synthesis, I report the range of observations (see figs. 5-9) of displacement (D), opening (O) and length (L) associated with the surface breaks as summarized from the various authors (i.e. Basili et al., 1998; Cello et al. 1998; Cinti et al. 1999; Vittori et al., 2000). For the original data and complete descriptions refer to the cited references. The range of the measurement values at some sites reflects slip variability, from the description of individual teams of geologists; at other sites, it reflects different values reported by different surveyors. As I will discuss, these latter disagreements contributed to diverging interpretations of the surface data.

At 09:40 UTC (hereafter called «09:40») a second normal faulting event $\left(\mathrm{M}_{\mathrm{w}} 6.0\right)$ occurred just north of the Colfiorito village (fig. 2). At 
that time, several teams were in the field for inspection and many others were on the way. The initial reconnaissance was based on the distribution of damage and environmental effects, and was guided by the geological literature (official geological and structural maps and Quaternary fault maps) and by the early hypocentral estimations. Although it was important to collect information on everything that occurred at surface, major efforts were undertaken to identify possible surface fracture systems and/or coseismic surface faulting.

The general features of the observed ground ruptures commonly agreed upon by all teams of investigators can be summarized as follows: Most of the features were either linear single fractures or fracture swarms, affecting paved and unpaved roads, buildings, soil and hard rock. The ruptures frequently showed en echelon geometry and extended continuously for tens of meters, with prevailing NW-SE to NNWSSE direction. The deformation was mainly expressed by open fractures ( 1 to $20 \mathrm{~cm}$ wide), locally characterized by centimetric vertical movement and a minor left lateral component. Several ruptures in the 26 September epicentral areas occurred on pre-existing and mapped fault planes at the contact between bedrock and slope debris. Figure 3 shows the first maps of the surface displacements published by different groups after the third major event in October; a synthesis is reported in fig. 4.

Besides the Costa site (described above), most of the significant ruptures were observed along the northeastern slope of the Colfiorito basin (Le Scalette Mt. and La Pintura sites) and on the western slope of Tolagna Mt. Minor movements formed also in the flat area of $\mathrm{La}$ Palude, and along the western slope of Pennino Mt. (see fig. 4 for locations and figs. 5 to 7 for illustrations and descriptions). Along the slope of Mt. Le Scalette (fig. 5c), discontinuous down-slope movements $(\sim 2 \mathrm{~cm}$, few hundred meters long) were observed at the contact between the debris cover and the pre-existing fault plane (125N-135N-striking, bedrock scarp). To the southeast along the basin margin, at La Pintura site, a road was crossed by ruptures consisting of $135 \mathrm{~N}$ to $145 \mathrm{~N}$-trending, $2-4 \mathrm{~cm}$ open cracks with a right-stepping en-echelon geometry (fig. 6a). Most authors do not report vertical displacement in this area, but this is another point of debate. Along the western slope of Tolagna Mt., open cracks and fissures developed
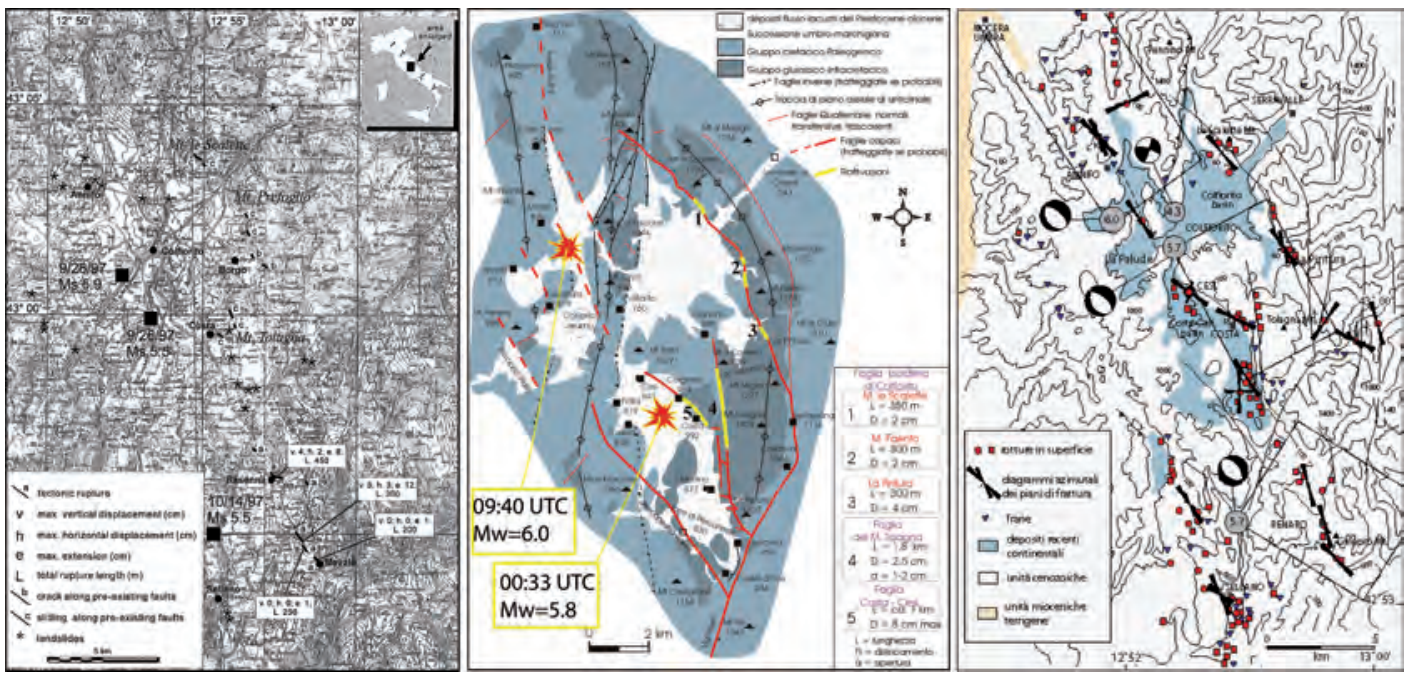

Fig. 3. First distributions of the surface ruptures published by different groups of surveyors. From left to right: Cello et al. (1998); Basili et al. (1998); Cinti et al. (1999). 


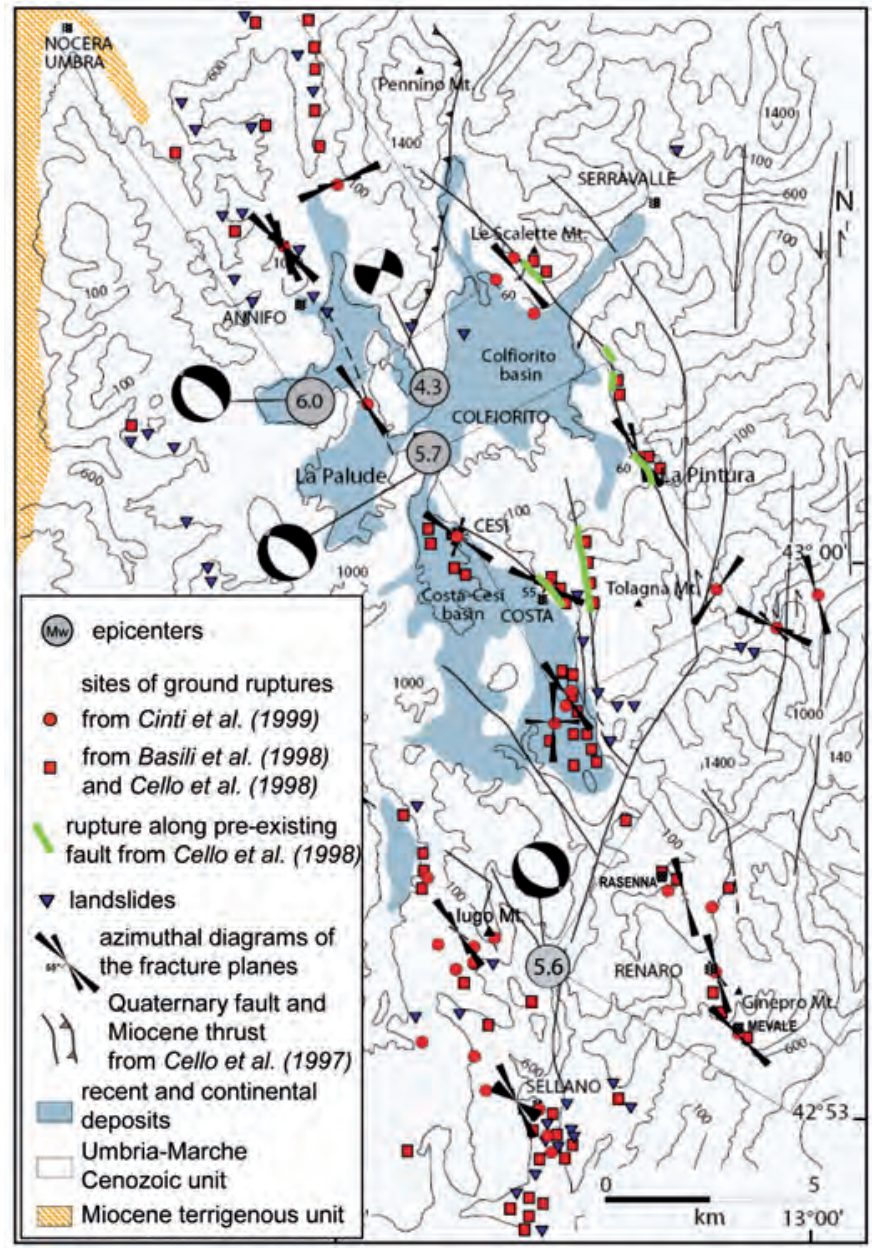

Fig. 4. Map showing a synthesis of the coseismic ground ruptures sites from the different teams (modified by Cinti et al., 2000). The rose diagrams show the azimuth of fracture planes (some of them refer to multiple sites) and the dip of the planes where observed (from Cinti et al., 2000). Dotted rectangles indicate the upward projection of the mainshocks rupture planes (Capuano et al. 2000; Hunstad et al. 1999; Salvi et al. 2000; Amato et al., 1998).

for hundreds of meters along the base of a bedrock fault plane (160N-140N striking), where a dark brown band suggested about $3 \mathrm{~cm}$ of vertical movement (fig. 6b). Interestingly, in the northern area struck by the $M_{w} 6.0$ (9:40) event only a few intermittent cracks formed. They developed transverse to the rock beds of Pennino Mt., which is a steep SW-dipping monocline formed by alternating limestone and clay layers. Cinti et al. (2000) suggest that the surface deformation in the area of Pennino Mt. was locally accomodated by diffuse slip on the bedding planes. A white strip at the base of the exposed bedrock was also observed, which may be due to sliding of the scree (fig. 7).

The Costa movements had been observed before the 09:40 event and thus they are likely associated with the early morning (00:33) 

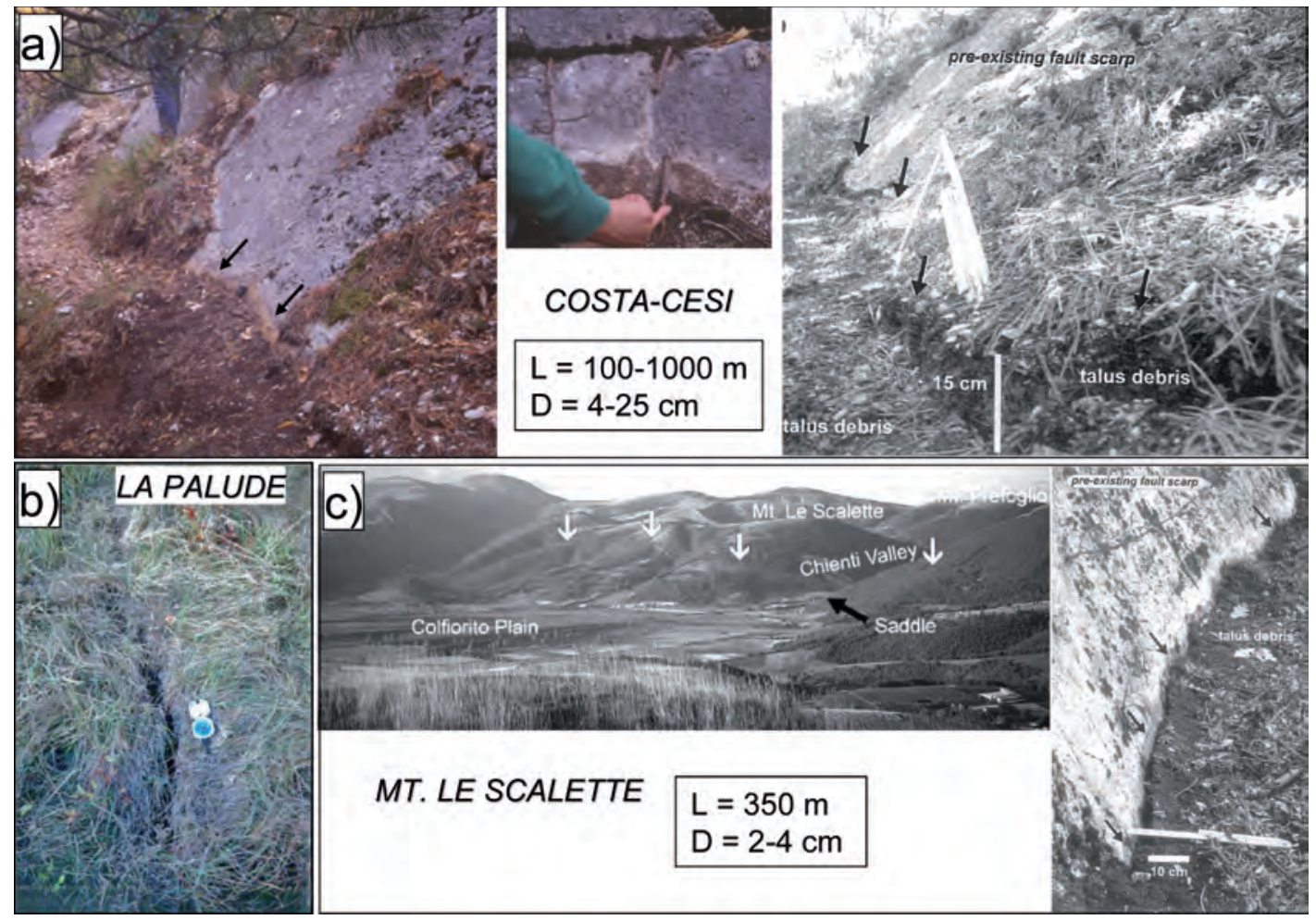

Fig. 5a,b,c. a) Left: Fresh exposure of the Costa bedrock fault scarp marked by a dark brown strip of soil, which is indicated by black arrows (photos courtesy of E. Tondi). This feature is interpreted by Cello et al. (1998) as reactivation of the fault plane. Middle: Detail of the exposure at the Costa site. The strip height and also offset roots were used as slip indicators on the fault plane. Right: Detail of a feature near the village of Costa interpreted by Basili et al. (1998) as a gravitational structure affecting debris slope (arrows point to the scree band; photo from Basili et al., 1998). The white bar indicates the height of the exposure; b) A 500 m-long set of open fractures (N145 average trend, $\mathrm{O}_{\max }=5 \mathrm{~cm}$ ) in a ploughed field by the flat area of La Palude (photo by F.R. Cinti); c) Panoramic view of the Colfiorito basin from south-east looking north. White arrows indicate the bedrock fault scarp (photo from Messina et al., 2002). To the right: the arrows point to the scree band observed along the Mt. Le Scalette fault plane (photo from Basili et al., 1998), where the hanging-wall debris cover detached from the smooth fault plane. Symbols: $\mathrm{L}=$ Length, $\mathrm{D}=$ Displacement.

event; according to Cello et al. (1998) no additional displacement on these fractures were observed in the following months. Except for this site, it is not possible from field observations alone to discriminate which of the two 26 September events caused the mapped surface features. However, event-specific contribution to the displacements was detected through analyses of geodetic data (see i.e. Salvi et al., 2000; Basili and Meghraoui, 2001).

At 15:23 UTC on 14 October, a $\mathrm{M}_{\mathrm{w}} 5.6$ nor- mal-faulting earthquake hit the area of Sellano (figs. 2 and 4), about $12 \mathrm{~km}$ south of the September epicenters, and the attention turned to this area. A rather continuous and prominent extensional fracture system was found cross-cutting different surface morphologies in limestone and in Holocene alluvium/colluvium at several sites (see fig. 4 for locations and figs. 8-9 for illustrations and descriptions). Near the village of Rasenna, a $\mathrm{N} 135^{\circ}-\mathrm{N} 150^{\circ}$-striking fracture system was formed and showed a maximum vertical 

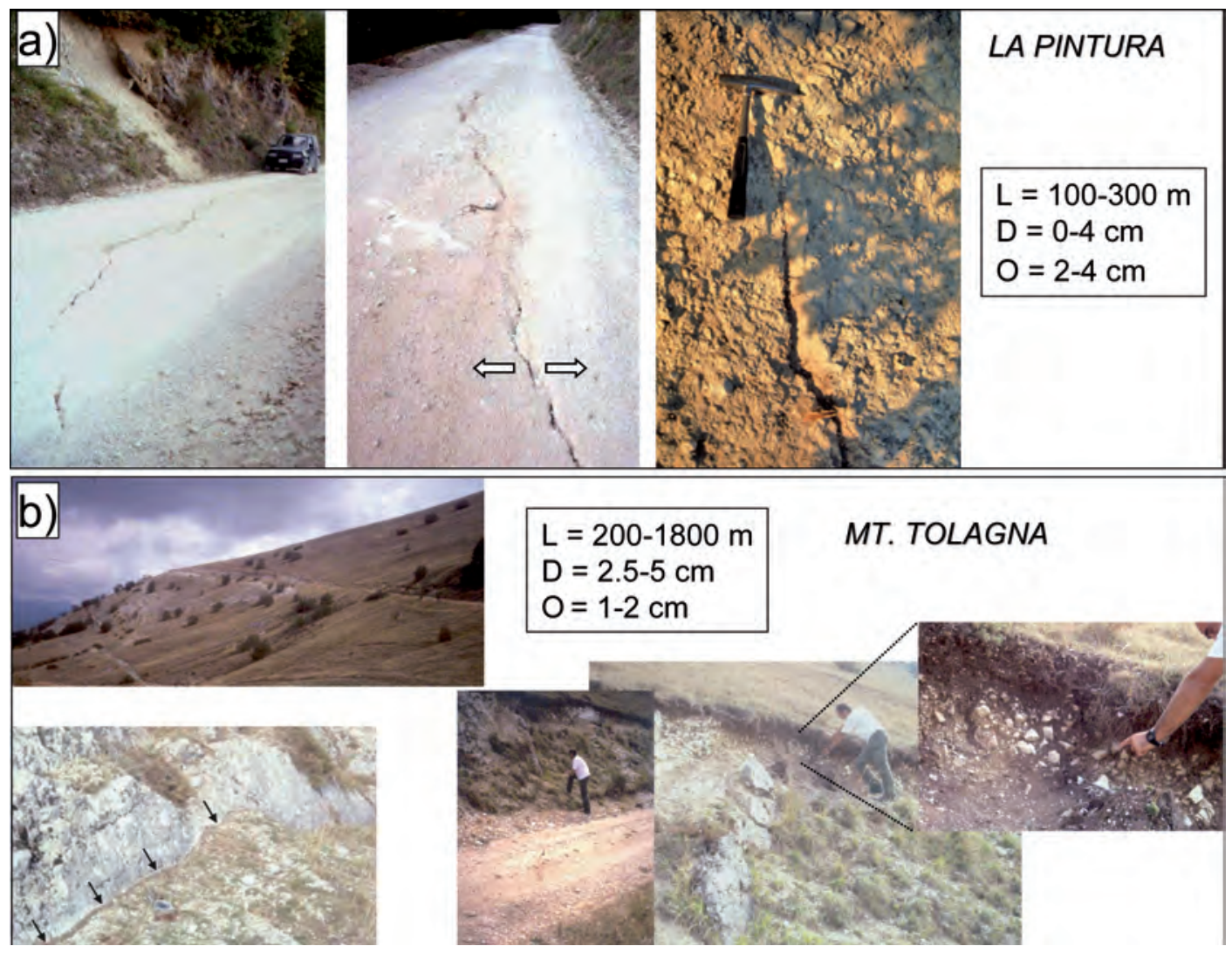

Fig. 6a,b. a) Discontinuous set of extensional fractures on a road at La Pintura site, which is coincident with a normal fault separating Mesozoic formation from late Quaternary deposits outcropping on the adjacent slope. Fractures generally have a right-stepping geometry: extension and small vertical offset occurs on the $135 \mathrm{~N}$ to $145 \mathrm{~N}$-oriented segments, while NS-oriented segments appear closed, suggesting a left lateral component of motion (photos from Cello et al., 1998). To the right: fissure in Quaternary deposits formed adjacent to the pre-existing fault plane (photo by P. Montone); b) View of the Mt. Tolagna fault scarp (upper left). To the right: fractured road and, according to Cello et al. (1998), reactivated bedrock fault plane showing a free-face (brown strip pointed by the arrows in photo to the lower left), and crack in hillslope deposits (person is pointing the feature). Photos courtesy of E. Tondi. Symbols: $\mathrm{L}=$ Length, $\mathrm{D}=$ Displacement; $\mathrm{O}=$ Opening.

offset of $\sim 10 \mathrm{~cm}$ (not illustrated). Locally, these fractures had a right stepping en-echelon pattern, which was probably related to a minor sinistral component. According to Basili et al. (1998), the total length of the zone was about $3 \mathrm{~km}$. Between the villages of Renaro and Mevale, a series of extensional fractures $\left(\mathrm{N} 140^{\circ}\right.$ average strike) formed along a distance of at least $1000 \mathrm{~m}$ (fig. 8). As much as $10 \mathrm{~cm}$ wide, they showed an av- erage vertical displacement of $5 \mathrm{~cm}$ and a maximum value of $15 \mathrm{~cm}$, northeast side up, and a minor left-lateral component (max $5 \mathrm{~cm}$ horizontal) (Cinti et al., 1999). The breaks climb through the Ginepro Mt., where they become parallel to the NS-striking cleavage of the strata along the slope (fig. 8). Basili et al. (1998) report that the opening of the fractures at Renaro had increased a few $\mathrm{cm}$ by 15 days after the earthquake. Local 


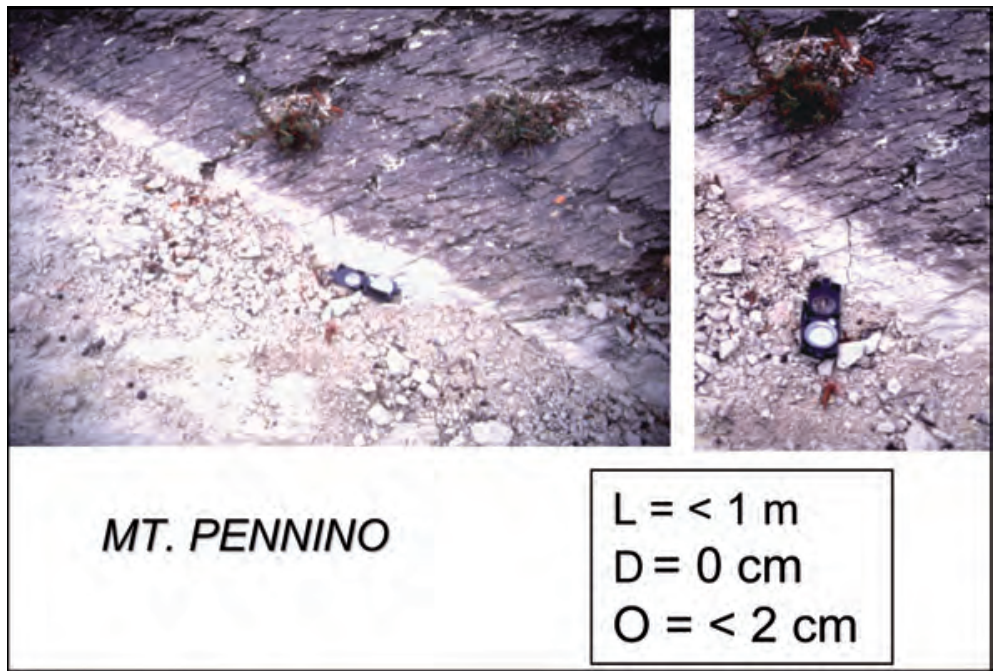

Fig. 7. Few $\mathrm{cm}$ long cracks formed transverse to the rock beds of the Pennino Mt. White strip at the base of the dark varnished bedrock is possibly related to sliding of the scree. Detail to the right (compass lies parallel to crack; photos by P. Montone). Symbols: $\mathrm{L}=$ Length, $\mathrm{D}=$ Displacement; $\mathrm{O}=$ Opening.

deformation also occurred just SSE of Sellano at the Cappuccini site, where ruptures defined a $\sim 600 \mathrm{~m}$-long, $100 \mathrm{~m}$-wide zone of fracturing along a paved road and extended into bedrock outcrops (fig. 9a). To the north, in the Mt. Lugo area, extensive NW-trending fractures were reported by Cinti et al. (1999). Here, the zone of fracturing is $\sim 30 \mathrm{~m}$-wide, and the en-echelon pattern of the segments shows a left lateral component to the motion (fig. 9b). Deformation in both the Mt. Lugo and Cappuccini areas was first observed prior to the mainshock of 14 October during the fieldwork by Cinti et al. (1999). This southward migration of the deformation from the zone of Colfiorito to Sellano, observable from the fieldwork, was later detected through a detailed analysis of the seismicity (Chiaraluce et al., 2003). Post-event re-survey showed substantial increases of the breaks, both in length and opening.

\subsection{Debate on the interpretations of surface data}

A contentious debate quickly arose over the seismotectonic interpretation of the surface fractures. Although the hypocenters were quite shallow, the earthquake magnitudes did not exceed M6 and consequently many of the coseismic surface effects produced were at the threshold of detection and generally faint. However, I believe that this could only partially explain the different amplitudes and directions of slip measured by the surveyors. For clarity, I will differentiate the interpretations of features associated with the 26 September epicenters from those of the 14 October event.

For the first observations (including the Mt. Le Scalette, La Pintura, and Costa sites), two contrasting interpretations and a third that combined elements of both, were provided by different authors. These are summarized in fig. 10 and substantially are as follows: 1) Cello et al., 1998; Vittori et al., 2000 (among others) interpreted the surface fractures as primary surface faulting. They claim that coseismic surface slip occurred along pre-existing Quaternary faults responsible for the recent tectonic evolution of the area. The amount of displacement they observed $(4-8 \mathrm{~cm})$ over lengths of a few $\mathrm{km}$ is what one should expect for $M_{w}=5.7-6.0$ events 


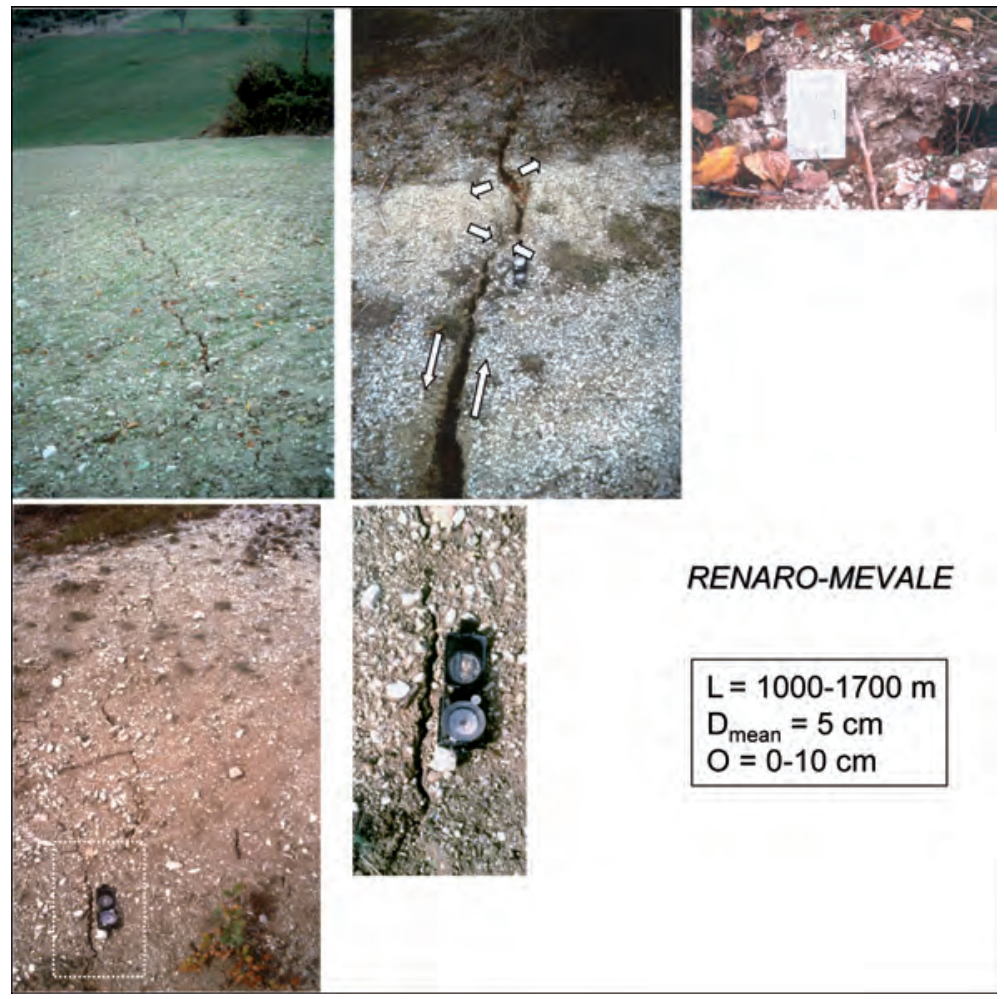

Fig. 8. Fractures south of the Renaro village affecting both recent colluvium/alluvium deposits and bedrock. Maximum horizontal offset of $\sim 5 \mathrm{~cm}$ is measured by a dirt road (photo in upper middle); arrows illustrate the sense of slip on fractures. Upper right: detail of open fracture with vertical displacement (maximum value of 15 $\mathrm{cm}$ ), northeast side up (photos by F.R. Cinti and F. Marra). Frequent right stepping en-echelon geometry of the fractures was observed on the hill top near Ginepro Mt. (lower photos; white box is the detail to the right; photos by F. Marra). Symbols: $\mathrm{L}=$ Length, $\mathrm{D}_{\text {mean }}=$ Vertical Displacement; $\mathrm{O}=$ Opening.

based on empirical database for earthquake faulting (i.e. Wells and Coppersmith, 1994). They inferred that ground displacement was related to fault slip rather than ground failure due to shaking. In fact, the authors argue that where fractures occurred along reactivated fault segments, surface offset was remarkably constant over tens to several hundreds of meters, while the thickness of slope deposits varied considerably, from a few $\mathrm{cm}$ to tens of $\mathrm{m}$. Moreover, comparable displacements were observed at sites showing different morphological features, and slope deposits were in dry and generally stabilised by tree root penetration. The authors infer that the seismogenic fault propagated to the surface and that its geometry, as suggested by seismic reflection data, is a $40^{\circ}-45^{\circ}$ dipping earthquake plane that splays upward into three synthetic and antithetic high angle fault branches (see sketch 1 in fig. 10). 2) According to others (i.e. Basili et al. 1998; Galli \& Galadini, 1999), the movements observed at the surface were not fault reactivations, but earthquake-induced sliding of debris. The ruptures were «apparent», occurring in correspondence with very steep slopes and with components of movement in accordance with the maximum slope direction. The authors claim that: almost all sites showed displacement as the result of scree or vegetal soil sliding along planes which usually 

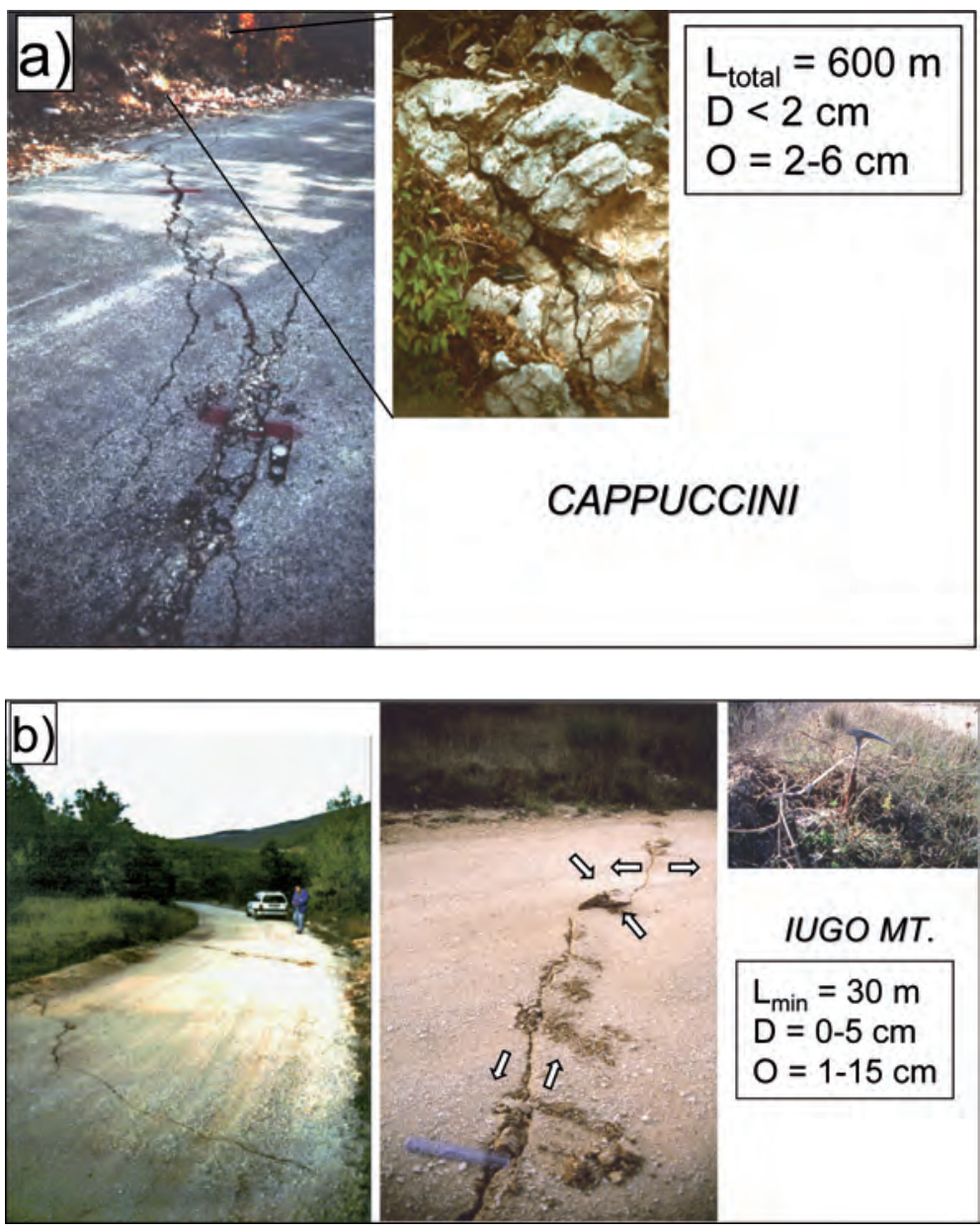

Fig. 9a,b. a) Ruptured paved road at the Cappuccini site, south of the village of Sellano, where a set of N135 $\mathrm{N} 155^{\circ}$ trending fractures extends into bedrock outcrops (see detail to the right) (photo by L. Cucci); b) Fractures break across an unpaved road in the Mt. Iugo area. Extensional and compressional features are observable in the middle photo. The en-echelon pattern of the segments shows a left-lateral component to the motion (arrows illustrate the sense of motion; $20 \mathrm{~cm}$ long ruler for scale). Deformation in the form of cracks and mole tracks was followed for few tens of meters beyond the road (detail to the upper right; photos by F.R. Cinti and L. Cucci). Photos are taken after the 14 October event. Symbols: $\mathrm{L}=$ Length, $\mathrm{D}=$ Displacement; $\mathrm{O}=$ Opening.

coincide with bedrock fault planes; the lengths of the observed surface breaks ( 500 m) represent a very small portion of the total length of the Quaternary active faults; the surface breaks occurred at the contact with Quaternary deposits and did not affect the nearby carbonate basement, where the fault plane was visible; many of the dislocations had both a left-lateral component on the right side and a right-lateral component on the left-hand side of stream incisions crossing the slopes, which clearly indicate a non-tectonic origin. Based on this interpretation and on the aftershock distribution, the authors hypothesize a listric fault plane whose 


\section{September ground ruptures}

1-PRIMARY SURFACE FAULTING (ite. Cello et al, 1998; Vittori et al, 2000)

- tectonic surface rupture, direct expression of the displacement at depth

$\checkmark$ evidence of reactivations of faults

$\checkmark$ fault activity responsible for the recent evolution of the Colfiorito basin

\section{2 - GROUND RUPTURES DUE TO SHAKING EFFECTS}

$\checkmark$ effects without any relation to slip at depth

(i.e. Basili el at. 1998; Galli \& Galadint. 1999)

dislocations result from gravitational phenomena induced by strong

shaking, locally visible along fault planes

$\checkmark$ earthquakes originated at deep portion of bordering faults

\section{3 - SECONDARY SURFACE FAULTING $(i, \theta$ Cinti $\theta t$ at, 1999)}

tectonic ruptures occur on secondary fault planes; locally superimposed on movements of slope debris

dislocations occur on weak preexistent zones, where high levels of shaking induce ground movements and minor slip along faults

- surface slip accomodates deformation at large scale, induced by deep displacement
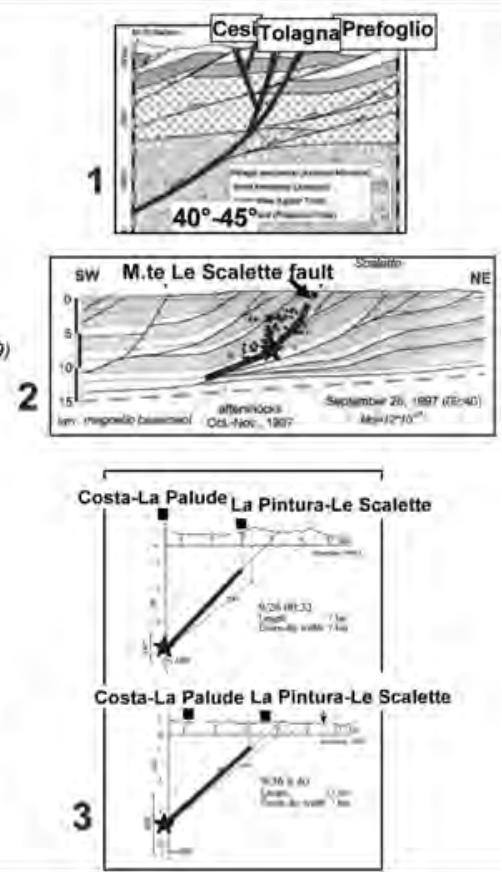

Fig. 10. Three different interpretations of the ground ruptures and of the fault plane geometry associated with the 26 September earthquakes (corresponding sketches to the right): 1) primary surface faulting and listric fault geometry at depth by Cello et al. (1998); 2) blind faulting and shaking-related ground failure by Galli and Galadini (1999); 3) secondary surface slip and postulated geometry of seismogenic fault (assuming constant dip) by Cinti et al. (1999). Sketch to the right: black squares indicate the location of ground ruptures; location of hypocenters and relative errors are from Amato et al. (1998).

rupture was confined to $1-2 \mathrm{~km}$ below the surface (see sketch 2 in fig. 10). 3) Still other surveyors (i.e. Cinti et al., 1999) concluded that the observed features were associated with triggered slip on secondary extensional faults that accommodated the deformation on a broad scale. Thus, most of the ground ruptures have a tectonic origin, although at some sites phenomena such as slope failure and compaction of loose sediments were superimposed. In these areas, the authors argue that minor amounts of both left and right horizontal motion were found, no ruptures occurred in bedrock, and the amount of slip observed at sites was highly variable and controlled by local topographic and near-surface geological conditions (similar argumentations reported by authors in interpre- tation n. 2). Cinti et al. (1999) emphasized that most of the ground ruptures formed locally continuous zones of deformation whose trends are consistent with the regional stress fields and that lie on or near known Quaternary faults. However, they noted that the zones of ground rupture are significantly shorter than the cumulative length of the three fault- rupture planes. This interpretation was supported by the lack of correspondence between the location of surface fractures and the up-dip surface projection of the rupture planes (sketch 3 in fig. 10; the red line is the most reliable fault plane solution from seismological data for a constant dip through the entire seismogenic volume). Fractures localized close to the vertical projection of the rupture tip and in the hanging wall of the fault. 


\section{October ground ruptures}

\section{1-QUESTIONABLE TECTONIC NATURE (i.e. Cello et al, 2000; Vittori et al, 2000)}

$\checkmark$ most likely gravitational phenomena; sackung-type

possibly secondary faulting

\section{2 - TECTONIC ORIGIN (i.e. Basifi et al., 2000; Cinti et al., 1999; Galli \& Galadini, 1999)}

$\checkmark$ direct surface expression of the seismogenic structure

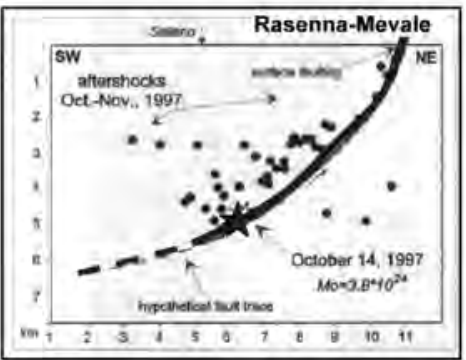

veismogenic blind fault: reactivation or activation of a secondary shallow structure (fault or joint)
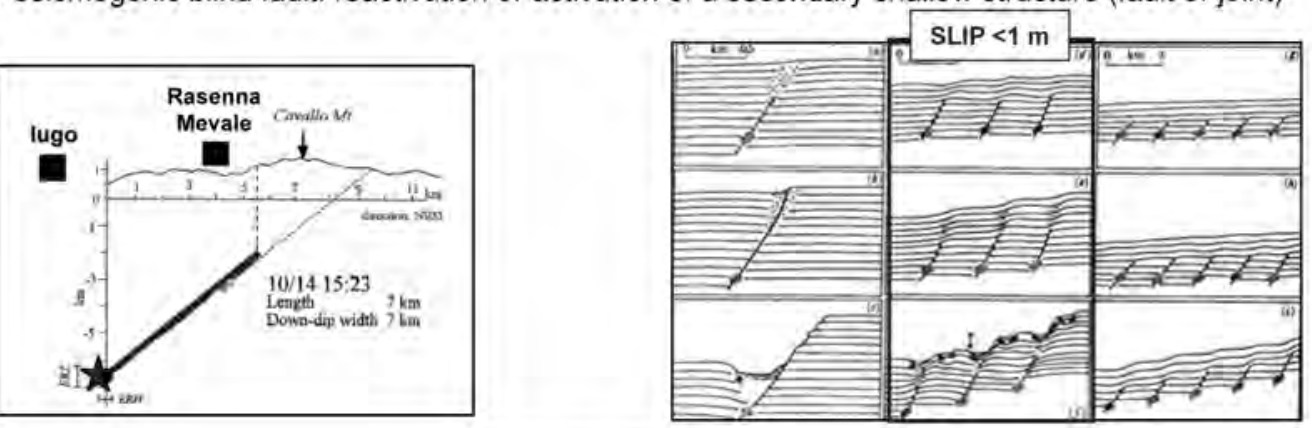

Fig. 11. Different interpretations of the ground ruptures and of the fault plane geometry associated with the 14 October event. Sketch corresponding to the surface faulting interpretation shows a hypothetical section of the earthquake plane reaching the surface by Galli and Galadini (1999). Sketches corresponding to the blind fault hypothesis: to the lower left is shown the relative location of ground ruptures (black square) and fault plane (assuming constant dip) by Cinti et al. (1999); to the lower right are the hypotheses of alternative surface expressions that relate to slip at depth, by Vita-Finzi and King (1985). The red box may reproduce the Umbria-Marche case: the surface is characterized by secondary structures including folding, but the main faults do not reach the surface.

There was more agreement in interpreting the deformation associated with the 14 October Sellano event as tectonic ruptures, primary or secondary faulting (i.e. Basili et al. 1998; Cinti et al., 1999; Galli \& Galadini, 1999), although a few authors (i.e. Vittori et al., 2000) questioned the tectonic significance of the features and highlighted possible gravitational phenomena (fig. 11). However, it is worth noting that part of the deformation in the Sellano area was 

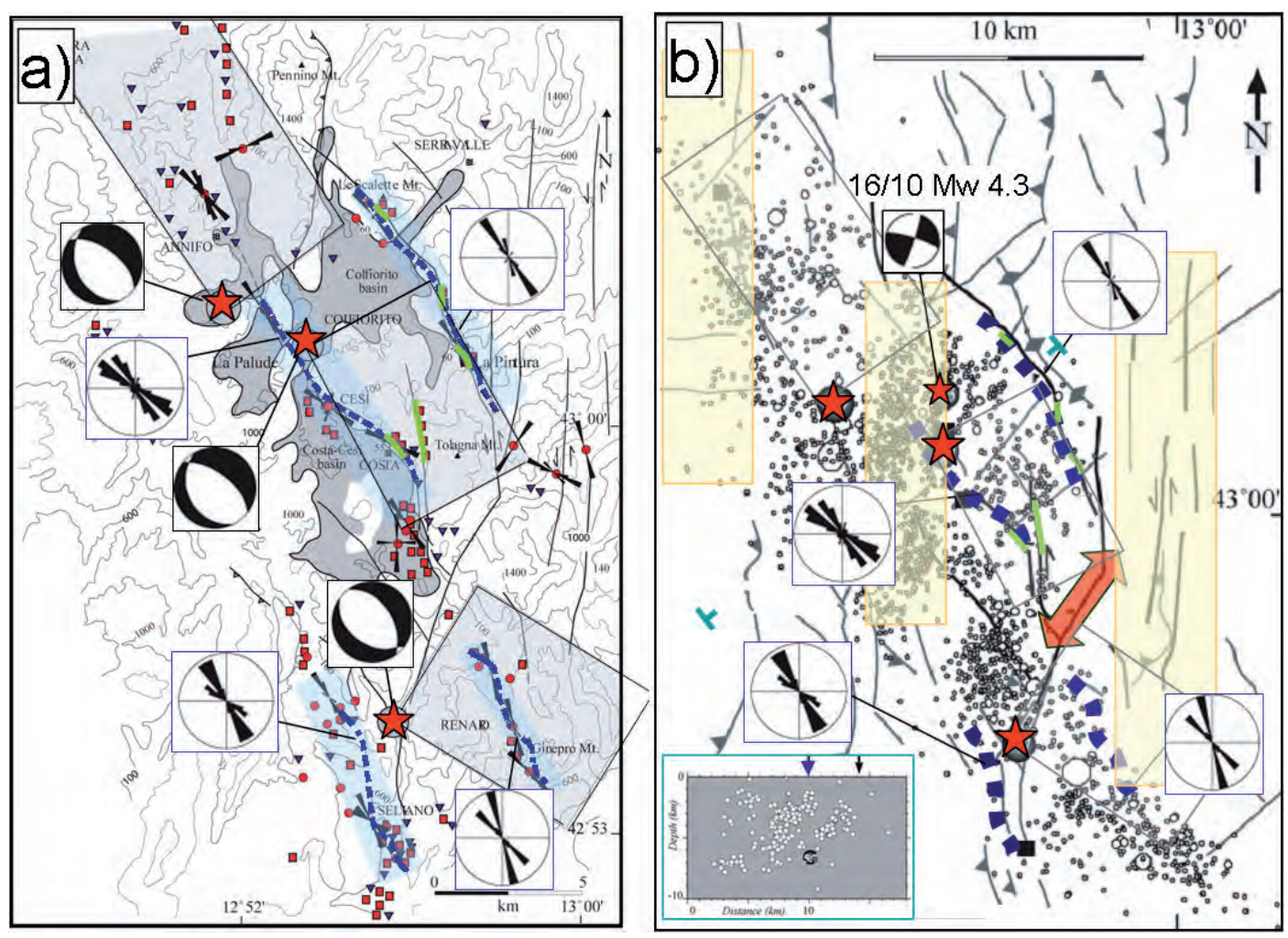

Fig. 12. a) Four inferred zones of ground breaks (blue dashed lines), maximum width of $1.5 \mathrm{~km}$ (blue rectangles include the sites of measurements belonging to each zone). The two northern zones are $\sim 9 \mathrm{~km}$ long and those to the south are $\sim 5 \mathrm{~km}$ long. Azimuthal diagrams of orientation of all ground ruptures for each zone are compared to the focal mechanism of the largest events and to the area of their fault plane (Capuano et al. 2000; Hunstad et al. 1999; Salvi et al. 2000; Amato et al., 1998). Green solid lines are ruptures along pre-existing fault; b) Comparison between zones of ground breaks (blue dashed lines) (Cinti et al., 1999) and aftershock distribution (Amato et al., 1998). Red arrow indicates the right step between the northern and southern fracture zones, the September and October fault planes, and the aftershocks distribution (modified by Cinti et al., 2000). Yellow rectangles includes NS shear zones inferred from trends of the mapped faults (grey lines, from Cello et al. (1997)), and geological and geomorphic observations (Cinti et al., 2000; Marra et al., 2000). A Mw 4.3 event on 16 October event had its epicenter within one of these shear zones and seismological data indicate it occurred on a NS striking, left-lateral fault plane. On the lower left, seismicity distribution along a SW-NE vertical section from Deschamps et al. (2000) (see dark green marks in fig. for profile location); the location of Costa-Cesi zone of ground breaks is indicated by the blue arrow in the cross section.

first documented prior to the mainshock of 14 October during the fieldwork by Cinti et al. (1999), and it showed a substantially increased post-event. One interpretation from Cinti et al. (1999) is that the southern area of Sellano was getting ready for the major failure on the 14 October and was being tectonically deformed.
This is in accordance with the hypothesis of secondary faulting within a broad zone of deformation.

A contribution to the debate on the significance of the geological effects comes from the aftershock and slip distribution (see following section for fault modelling), which revealed 
that the earthquake ruptures died out at around $1 \mathrm{~km}$ depth (e.g. Chiaraluce et al., 2003). Only the fault rupture of the "9:40" 26 September main shock $\left(M_{w}=6.0\right)$ seems to be shallower than $1 \mathrm{~km}$. Another significant result from seismological analyses is that all the activated segments show a planar geometry, without any flattening or evidence for listricity at depth (e.g. Amato et al. 1998; Chiaraluce et al., 2003).

The above described differences in interpretation are significant for hazard assessment. Length and slip of the seismogenic fault are parameters used for the estimation of seismic moment, and the issue of whether ground ruptures are primary fault rupture has implications for whether their extent and displacement can be used to estimate rupture dimension and thereby forecast the magnitudes of future earthquakes.
The goal of this paper is not to provide a final answer in this case, and I prefer to look beyond differences in interpretation and analyze general aspects of the surface data that may help us comprehend the mechanism of rupture, independent of the origin of the features. First, in the next paragraph, I will discuss other types of data collected during the post-earthquake inspections related to the earthquake distribution, mechanism of rupture, and coseismic deformation.

\subsection{Surface data vs seismological and InSaR data}

The Umbria-Marche sequence provided the rare opportunity to compare data of local surface

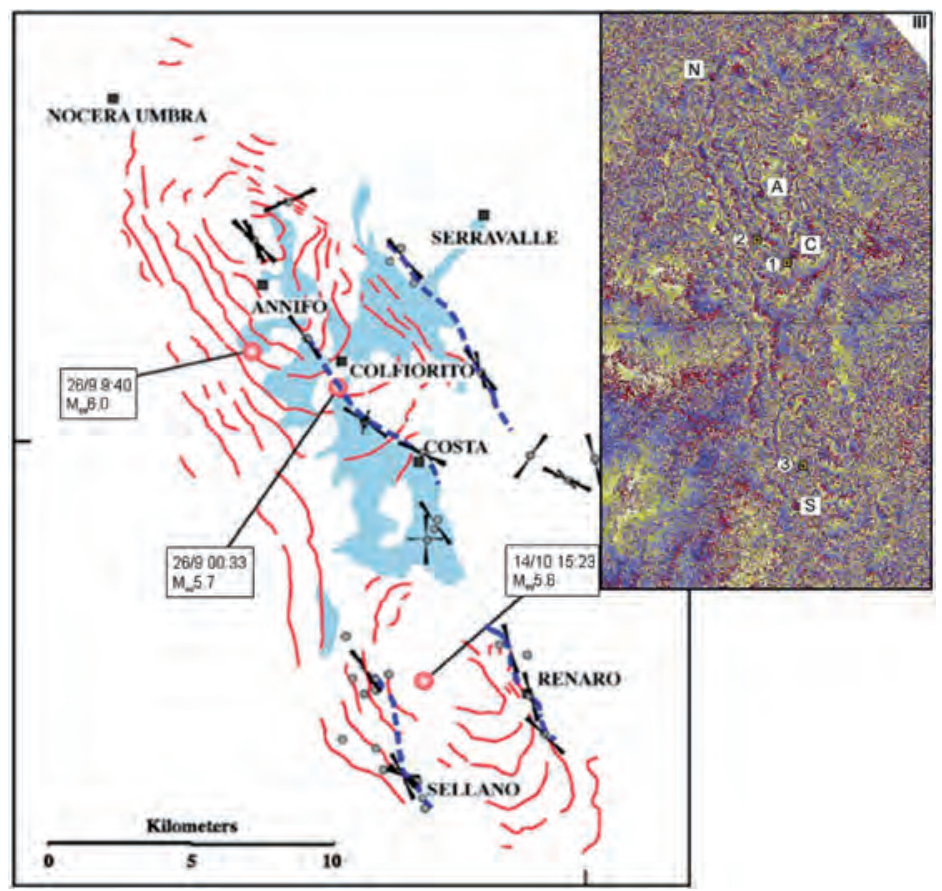

Fig. 13. Inferred zones of surface fractures (blue dashed lines) and interpreted interferometric fringes from Salvi et al. (2000) (modified from Cinti et al., 2000). Each contour line indicates an increase of the satellite-to-ground distance of $28 \mathrm{~mm}$. A maximum increase (subsidence) is in and north of the epicentral areas. To the right: Differential interferogram of the entire sequence by Salvi et al. (2000). Each contiguous inward colour cycle represents a displacement increment of $-28 \mathrm{~mm}$. Symbols: 1 = "00:33" 26 September earthquake; 2 = "09:40" 26 September earthquake; 3 = "15:23" 14 October earthquake; A = Annifo; $N$ = Nocera Umbra; C = Colfiorito; S = Sellano. 
geology with a large and complete set of seismological and geodetic data, and to test the consistency of the interpretations of the surface breaks.

In order to facilitate comparisons, Cinti et al. (2000) arbitrarily linked the single sites of ruptures and inferred four parallel zones of deformation (fig. 12a). The zones to the north for most of their length follow mapped faults bordering the basins (fig. 12a), occurring in correspondence with steep slopes. In contrast, those to the south occur where no active faults were mapped and extend into different morphological settings.

From the agreement between fractures, focal mechanisms and modelled fault planes shown in fig. $12 \mathrm{a}$, we see that the surface data reflect: 1) the general orientation of the mainshock faults below the earth's surface (discrepancy of $\sim 30^{\circ}$ for the 14 October fault); 2) the prevailing extensional mechanism of ruptures (in the NE-SW direction); 3) the dip toward SW of the fault planes (although less constrained by few data). From fig. 12b, we see that the surface data follow: 1) the NW-SE elongation of the aftershock area; 2) the northeastern and southwestern boundaries of the aftershock distribution, except for the Costa-Cesi site, which is on the vertical projection of a secondary plane defined by the seismicity (see seismic section from Deschamps et al. (2000) in fig. 12b); 3) the $\sim 5 \mathrm{~km}$-wide right step in the fault planes and in the aftershock distribution. This «offset» is marked by transverse structures (see Quaternary faults from Cello et al. (1997)), possibly responsible for the southward stress transfer.

Since the first analysis of the ground deformation in conjunction with the structural setting of the area, many authors referred to a geometric control of the fault plane dimensions by pre-existing lineaments. Among others, Meghraoui et al. (1999) introduced the concept of «fault fragments» to explain the sequence: that is, the dimensions of the source faults for the three mainshocks are limited by transversal thrusts and by basement outcropping. In the map of fig. 12b, three main NS shear zones are inferred. The shear zone farthest to the east is represented by a series of sub-parallel N-striking faults (mapped by Cello et al., 1997), and the zone farthest to the west extending through Nocera Umbra has been deduced from geological and geomorphic observations by Marra et al. (2000). Both zones appear to confine the sequence; it was hypothesized that these act as structural barriers that control the dimensions of the seismogenic structure (Cinti et al., 2000; Marra et al., 2000). Surface observations from Cinti et al. (2000), such as the sharp and aligned west edges of the Colfiorito and CostaCesi basins (fig. 4), suggested the presence of a third N-S tectonic discontinuity in the area between the 26 September mainshocks. It is worth noting that a M4.3 shock occurred on 16 October (fig. 12b) in between the 26 September epicenters, on a NS striking, left-lateral fault plane (based on focal mechanism and seismicity distribution). Before the 16 October event, no faults had been associated with this plane, but the existence of the NS discontinuity at that site was inferred, and identified as the possible cause of the opposite propagation direction of the two ruptures (Amato et al., 1998; Cinti et al., 2000). All these concepts proposed at the beginning of the studies have been supported, refined and developed in the time after the seismic crisis by many researchers, using additional analysis of detailed seismological and structural data (e.g., for segmentation model of the faults see Chiaraluce et al., 2005; for the 16 October strike-slip sequence and fault reactivation analysis see Collettini et al., 2005).

Another view of the sequence comes from the mapping of the coseismic ground displacement field obtained by Stramondo et al. (1999) using the SAR Differential Interferometry (DInSAR) technique (see also Salvi et al., 2000; Lundgren and Stramondo, 2002). Figure 13 shows the relation between the location of the surface breaks and the dislocation field depicted by the interferometric fringes. The observations made by Cinti et al. (2000) from this comparison are: 1) the northeastern zone of surface breaks is located in an area of very low uplift (2-3 cm) (see Salvi et al., 2000; Moro et al., 2007 for detail); 2) the Costa-Cesi fractures formed along the southern portion of the axis of maximum subsidence, which occurred north of Annifo. Few sites of fractures were observed in this area of maximum deformation and most of 

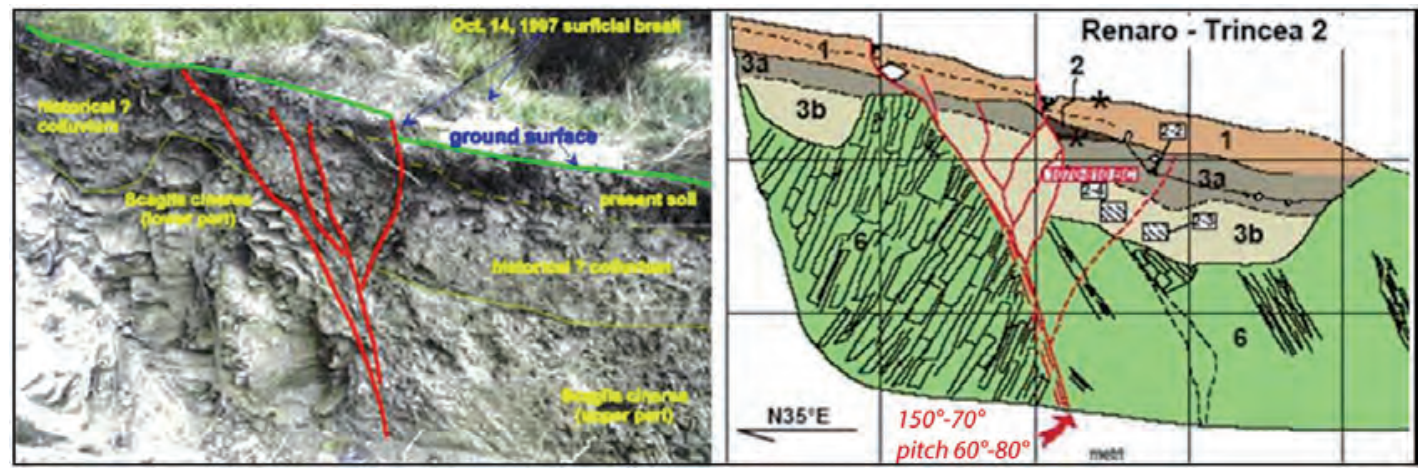

Fig. 14. View and log of the southern wall of the trench dug across the Renaro surface breaks (from Pantosti et al., 2000). The 1997 breaks correspond at depth to a well-defined fault zone. Suggestion for the occurrence of an event before the 1997 event comes from the larger displacement of Unit 3a with respect to that of 1997, along with a buried colluvial wedge (unit 2).

these were classified by several survey teams as landslide phenomena (i.e. Esposito et al. 2000); 3) the fracture zone of Renaro-Mevale coincides (in location and orientation) with a high gradient depicted by the fringes for the 14 October event. The zone of fractures north of and around Sellano (Mt. Lugo-Cappuccini) locates in a zone with lower gradient. Cinti et al (2000) concluded that the comparison between inferred linear ruptures and dislocation field indicates that the fractures were not random but represented the fragile accommodation of a vertical deformation at the large scale.

Several fault models have been developed using GPS and DInSAR data, and they do not converge to the same best-fit solutions. The fault model proposed by Salvi et al. (2000) suggests that the early 26 September rupture occurred on a blind fault, while the rupture of the "9:40" shock was shallower and intersected the surface. For this second event, Hernandez et al. (2004) inverted the geodetic data and obtained a modelled fault with a larger slip patch close to the hypocenter and a second smaller and shallower slip patch to the northeastern edge of the fault (area of Mt. Pennino). A different model for this fault is obtained by De Martini et al. (2003) from elevation changes analysis. These authors suggest a blind fault with variable slip. The models of a blind fault for the "9:40" September event show a general agreement with the very poor evidence of surface offsets in the area northwest of Colfiorito (including Annifo and Pennino Mt.).

\section{Geological input for seismic hazard evaluation}

In this section, I will focus on several issues brought forth by the 1997-1998 sequence that are important for the evaluation of seismic hazard in the region, as well as for areas with comparable seismotectonic characteristics. The 1997-1998 Umbria-Marche sequence confirmed the magnitude threshold of around 6 for which we expect significant surface fracturing. This is one of the most important outcomes of this seismic crisis, since it validates the possibility that geologists may contribute to the hazard assessment in areas characterized by moderate-size seismicity. Whether due to primary or secondary faulting, these sorts of faint surface effects may provide information on the seismogenic rupture. Moreover, a multidisciplinary approach and the conjunction of distinct data sets provide the best formula for characterizing the nature of surface faulting and its behaviour through time. If we determine that before the 1997 sequence, comparable earthquakes in the area generated similar ruptures and at some of the same sites, then we have the 


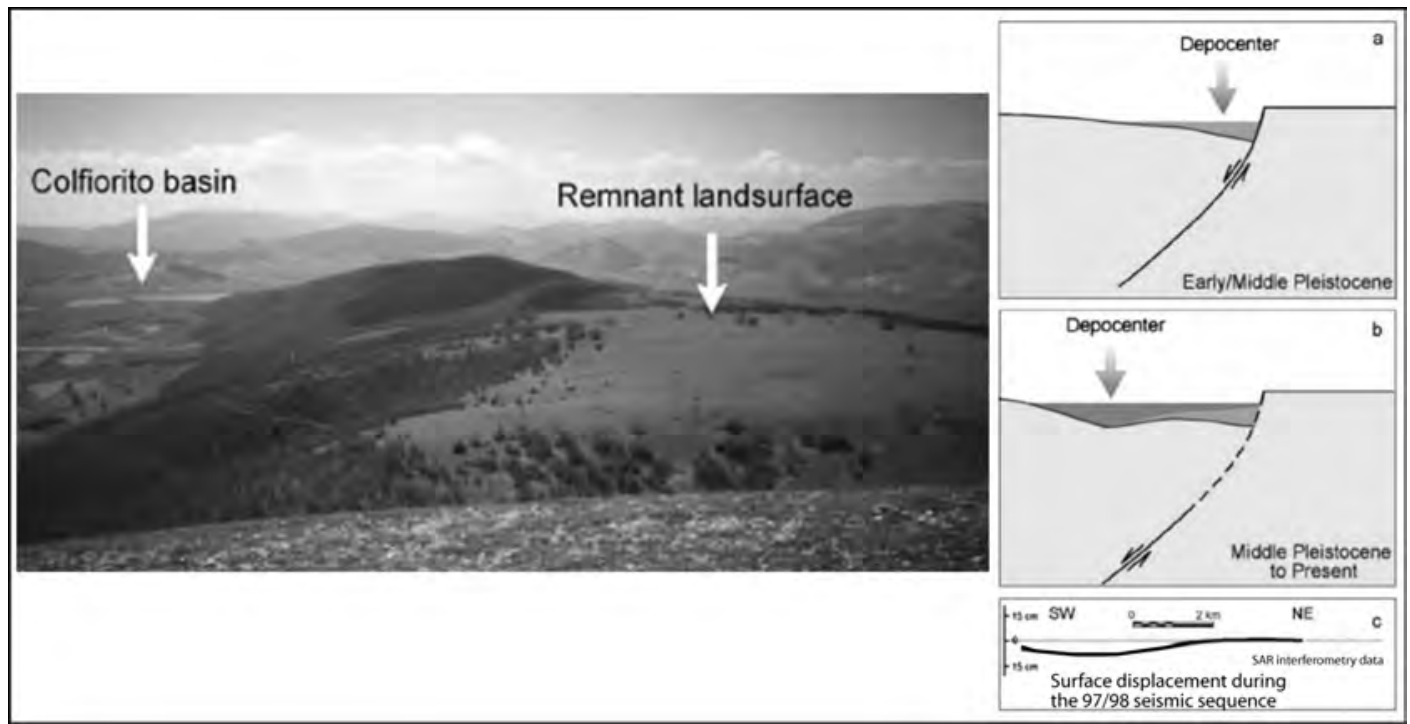

Fig. 15. View of a remnant land surface carved in carbonate bedrock above the Colfiorito basin (Messina et al., 2002). To the right is a two-part scheme for the evolution of the Colfiorito basin. Below that is the 1997 surface coseismic deformation as inferred from DinSAR (Messina et al., 2002). The maximum deformation (lowering) coincides with the deepest depocenter of the basin).

possibility of understanding how faults may fail in the future, the recurrence of such events, and rates of slip.

In hopes of characterizing the hazard, during the ten years after the sequence, geologists put their efforts into understanding the past seismic behaviour of the 1997-1998 seismic sources.

Two types of features were studied, the outcropping active faults and/or of the observed surface ruptures. Paleoseismological techniques have been the most fruitful for investigating the medium to short term behaviour of the surface-rupture-producing faults. To date, the only paleoseismological excavations across the surface ruptures were done by Pantosti et al. (2000) at the Renaro site (fig. 14). The trenches revealed that similar ruptures had occurred prior to 1997, suggesting a recurrence of the source with 1997-type earthquakes $\left(M_{\max }=6\right)$. Unfortunately, the interval of time defined for the penultimate event (170 B.C.- pre 1997) was too large for a direct comparison with the historical seismic catalogue. The authors could not discriminate between primary or secondary faulting, and generally speaking, when ruptures are related to secondary faulting (or especially landsliding or liquefaction) there is uncertainty in reconstructing the seismic history of a specific source. This uncertainty may be reduced through additional constraints, such as the collection and analysis of data from many sites. Pantosti et al. (2000) used the observational record provided by local people for the last 5060 years led to exclude the possibility that the deformation prior to the 1997 at the Renaro site had been produced by the nearby 1979 and 1984 earthquakes (see fig. 1 for locations). The promising results of this study should encourage geologists to do further paleoseismological studies in the area.

Other studies have been conducted on the history of the basin bounding faults and particularly on the evaluation of cumulative coseismic displacements and long-term slip rates through geomorphological data analyses (field survey, DEM and aerial photointerpretation) (e.g. Cello et al., 2000). Messina et al. (2002) 
analyzed remnant land surfaces and borehole data to reconstruct the Quaternary evolution of the Colfiorito basin and to define the present tectonic regime (fig. 15). In contrast with other authors (i.e. Cello et al., 1997, 2000; Chiaraluce et al., 2005), they concluded that the evolution of the basin is no longer related to the bordering fault (see also De Martini et al., 2003 for evidence of present fault inactivity). Since Middle Pleistocene time, a new depression has been superimposed on the previous half-graben whose evolution is related to the lowering of the inner portion of the basin through warping (figs. 15a,b). Moreover, Messina et al. (2002) assert that the activity related to this younger depression does not result in fault-related surface displacements but only in "continuous» deformation spread over the basins (Messina et al., 2002). These results indicate that the diffuse deformation observed in the 1997 sequence and the locus of subsidence imaged by DinSAR (fig. 15c) reflects the long-term pattern of deformation. Based on this consistency, Messina et al. (2002) suggest that the recent history of the basins results from the cumulation of deformation episodes similar to those of 1997 (magnitude not larger than 6).

Finally, the sequence has focused attention on the role of tectonic fabric on controlling the dimensions of earthquake sources. As inferred for the 1997-1998 sequence (see section 3.2), geometric and structural discontinuity may provide information on the propagation behavior and dimensions of the faults, and consequently the earthquake sizes. In this regard, a detailed knowledge of the historic and paleoseismic history of the whole fault zone is required.

\section{A lesson to remember: perspectives on post-earthquake investigations}

The Umbria-Marche sequence was a test bed for post-earthquake intervention in the field. It taught us that: 1) it is critical to undertake an immediate field response and to coordinate interaction between researchers to compare the surface observations directly at site, in order to avoid later debates on the record of observations. Timely response is needed since the ground deformation undergoes changes in time, and minor effects are perishable. Discussions on interpretations should be necessarily left to after the emergency when time allows and other sources of data are available. However, the length, size and direction of fractures have to be documented as objectively as possible; 2) Monitoring of the region in time and space is critical to obtaining full coverage of the affected area. This is particularly true for long-lasting sequences characterized by multiple shocks with $M>5$ that can result in multiple episodes of deformation over a wide area. The southern area of the 1997 sequence was affected by ground movements before the nearby 14 October shock as testified by the significant surface fractures observed prior to that event. This may mean that from detailed fieldwork during a seismic crisis we can notice migration of deformation from one area to another; 3) Frequent updates on the development of the pattern of seismicity is important for guiding geologists in the field.

Last but not least, we had confirmation that increasing technological capabilities play an important role in field investigations. For example, most of the geologists in 1997 did not have high quality GPS receivers for precise mapping of the features observed in the field. Even digital cameras and telecameras were not common, so that it was not possible to view images in the field to make sure features were properly documented. The present technologies would allow a good video collection and a more efficient data archive.

From this experience, the earthquake science community became aware of the requirements and problems to be solved during a seismic crisis and it became the impetus for efficient initiatives to prepare for future possible events. Several groups involved in the full spectrum of earthquake investigations (GPS, strong motion, geotechnical, damage distribution, seismic network, geology) started to organize for post-earthquake response. Regarding earthquake geology, in 2002 scientists and technicians from the Istituto Nazionale di Geofisica e Vulcanologia (INGV) formed a team called EMERGEO for coordinating geological field surveys in areas hit by moderate-to-large earthquakes. Response protocol prescribes proce- 
dures to follow during the emergency and guidelines for collecting surface data in the field and for creating real-time maps.

The underlying message is that scientists have the responsibility to document the location and surface extent of fracturing in post-earthquake studies as completely and reliably as possible, both for immediate scientific and social benefit and to provide high-quality data to future investigators.

\section{Acknowledgements}

I am grateful to Francesca Di Luccio for providing the map of the Umbria-Marche instrumental seismicity, and to Luigi Cucci for fruitful comments on the manuscript. Special thanks to the referees, Suzanne Hecker and Francesco Salvini, that contributed to improve the paper with their comments and suggestions. This work was presented for the decennial of the Umbria-Marche sequence at the Workshop «Colfiorito 1997-2007: Evoluzione degli Studi di un Terremoto» INGV-UniRoma3 (Rome, 810 October 2007).

\section{REFERENCES}

Amato, A., R. Azzara, C. Chiarabba, G.B. Cimini, M. Cocco, M. Di Bona, L. Margheriti, S. Mazza, F. Mele, G. Selvaggi, A. Basili, E. Boschi, F. Courboulex, A. Deschamps, S. Gaffet, G. Bittarelli, L. Chiaraluce, D. Piccinini and M. Ripepe (1998): The Colfiorito, Umbria-Marche earthquake sequence in central Italy (Sept.-Nov., 1997): a first look to mainshocks and aftershocks, Geophys. Res. Lett. 25, 2861-2864.

Basili, R., C. Bosi, V. Bosi, F. Galadini, P. Galli, M. Meghraoui, P. Messina, M. Moro and A. Sposato (1998): The Colfiorito earthquake sequence of September-October 1997. Surface breaks and seismotectonic implications for the central Apennines (Italy), J. of Earth. Engin., 102 (2), 291-302.

Basili, R. and M. Meghraoui (2001): Coseismic and postseismic displacements related with the 1997 earthquake sequence in Umbria-Marche (Central Italy), Geophys. Res. Lett., 28 (14), 2695-2698.

BoniLla, M.G., 1988: Minimum earthquake magnitude associated with coseismic surface faulting, Bull. Assoc. Eng. Geol., 25, 17-29.

Boschi, E., E. Guidoboni, G. Ferrari and G. Valensise (1998): I Terremoti dell'Appennino Umbro-Marchigiano (Area Sud Orientale dal 99 a. C. al 1984), (INGSGA, Bologna, Italy).

Calamita, F. and A. Pizzi (1993): Tettonica quaternaria nella dorsale appenninica umbro-marchigiana e bacini intrappenninici associati, Studi Geologici Camerti, spec. vol. 92/1, 17-25.

Capuano, P., A. Zollo, A. Emolo, S. Marcucci and G. MilanA (2000): Rupture mechanism and source parameters of Umbria-Marche mainshocks from strong motion data, J. Seismol., Special Issue, 4, 463-478.

Carmignani, L., G. Cello, A. Cerrina Feroni, R. FuniCello, O. Kälin, M. Meccheri, E. Patacca, P. Pertusati, G. Plesi, F. Salvini, P. Scandone, L. TortoriCI and E. Turco (1981): Analisi del campo di fatturazione superficiale indotto dal terremoto campanolucano del 23/11/1980, Rend. Soc. Geol. It., 4, 451$465,12 f f$.

Castelli, V., G. Monachesi and M. Stucchi (1997): La sismicita' maggiore dell'Appennino Umbro-Marchigiano, Special Technical Report, Gruppo Naz. per la Difesa dai Terremoti (GNDT), Rome.

Castello, B., G. Selvaggi, C. Chiarabba and A. Amato (2005): CSI Catalogo della sismicità italiana 19812002, (versione 1.0. INGV-CNT, Roma, http://www.ingv.it/CSI/).

Cello, G., S. Mazzoli, E. Tondi and R. Turco (1997): Active tectonics in the central Apennines and possibile implications for seismic hazard analysis in peninsula Italy, Tectonophysics, 272, 43-68.

Cello, G., G. Deiana, P. Mangano, S. Mazzoli, E. Tondi, L. Ferreli, L. Maschio, A.M. Michetti, L. Serva and E. VITTORI (1998): Evidence for surface faulting during the September 26, 1997, Colfiorito (Central Italy) earthquakes, J. of Earth. Engin., 102 (2), 303-324.

Cello, G., G. Deiana, L. Ferreli, L. Marchegiani, L. Maschio, S. Mazzoli, A. Michetti, L. Serva, E. TonDI and T. VITTORI (2000): Geological constraints for earthquake faulting studies in the Colfiorito area (Central Italy), J. Seismol., 4, 357-364.

Chiaraluce, L., W. L. Ellsworth, C. Chiarabba and M. Cocco (2003): Imaging the complexity of an active normal fault system: The 1997 Colfiorito (Central Italy) case study, J. Geophys. Res., 108, B6, 2294, doi: 10.1029/2002JB002166.

Chiaraluce, L., A. Amato, M. Cocco, C. Chiarabba, G. Selvaggi, M. Di Bona, D. Piccinini, A. Deschamps, L. Margheriti, F. Courboulex and M. Ripepe (2004): Complex Normal Faulting in the Apennines Thrustand-Fold Belt: The 1997 Seismic Sequence in Central Italy, Bull. Seism. Soc. Am., 94, (1), 99-116.

Chiaraluce, L., M. Barchi, C. Collettini, F. Mirabella and S. PUCCI (2005): Connecting seismically active normal faults with Quaternary geological structures in a complex extensional environment: The Colfiorito 1997 case history (northern Apennines, Italy), Tectonics, 24, doi: 10.1029/2004TC001627.

Cinti, F.R., L. Cucci, F. Marra and P. Montone (1999): The 1997 Umbria-Marche (Italy) earthquake sequence: relationship between ground deformation and seismogenic structure, Geophys. Res. Lett., 26 (7), 895-898.

CinTI, F.R., L. CuCCI, F. Marra and P. Montone (2000): The 1997 Umbria-Marche earthquakes (Italy): relation between the surface tectonic breaks and the area of deformation, J. Seism., 4, 333-343.

Collettini, C., L. Chiaraluce, S. Pucci, M.R. Barchi and M. CoCCO (2005): Looking at fault reactivation match- 
ing structural geology and seismological data, J. Struct. Geol., 27, 937-942.

CPTI Working Group (2004): Catalogo parametrico dei terremoti Italiani, version 2004 (CPTI04), (INGV, Bologna. (Available at http://emidius.mi.ingv.it/CPTI).

De Martini, P. M., N. A. Pino, G. Valensise and S. MaZZA (2003), Geodetic and seismologic evidence for slip variability along a blind normal fault in the Umbria Marche, 1997.1998 earthquakes (central Italy), Geophys. J. Int., 155, 819-829.

Deschamps, A., D. IANNACCONE and R. ScARPa (1984): The Umbrian earthquake (Italy) of 19 September 1979, Ann. Geophys., 2, 29-36.

Deschamps, A., F. Courboulex, S. Gaffet, A. Lomax, J. Virieux, A. Amato, A. Azzara, B. Castello, C. Chiarabba, G.B. Cimini, M. Cocco, M. Di Bona, L. Margheriti, F. Mele, G. Selvaggi, L. Chiaraluce, D. PICCININI and M. RiPEPE (2000): Spatio-temporal distribution of seismic activity during the Umbria-Marche crisis, 1997, J. Seism., 4, 377-386.

Esposito, E., S. Porfido, A.L. Simonelli, G. MasTROLORENZO and G. IACCARINO (2000): Landslides and other surface effects induced by the 1997 Umbria-Marche seismic sequence, Engineering Geology, 58, 353-376.

Galli, P. and F. Galadini (1999): Seismotectonic framework of the 1997-98 Umbria-Marche (Central Italy) earthquakes, Seism. Res. Lett., 70 (4), 404-414.

Haessler, H., R. Gaulon, L. Rivera, R. Console, M. Frogneux, G. Gaparini, L. Martel, G. Patau, M. SiCiliano and A. Cisternas (1988): The Perugia (Italy) earthquake of 29, April 1984: A microearthquakesurvey, Bull. Seismol. Soc. Am., 78, 1948-1964.

Hernandez, B., M. Cocco, F. Cotton, S. Stramondo, O. Scotti, F. Courboulex and M. Campillo (2004): Rupture history of the 1997 Umbria-Marche (central Italy) mainshocks from the inversion of GPS, DInSAR and near field strong motion data, Ann. Geophys., 47, (4), 1355-1376.

Hunstad, I., M. Anzidei, M. Cocco, P. Baldi, A. Galvani and A. Pesci (1999): Modeling coseismic displacements during the 1997 Umbria-Marche earthquake, Geophys. J. Int., 139, 283-295.

IAEA (1991): Earthquakes and associated topics in relation to Nuclear Power Plant sitting. A safety guide, Safety Series, International Atomic Energy Agency, Vienna, 50-SG-S1 (Rev. 1), pp. 60.

LundGREN, P. and S. STRAMONDO (2002): Slip distribution of the 1997 Umbria-Marche earthquake sequence: joint inversion of GPS and synthetic aperture radar interferometry data, J. Geophys. Res., 107, B11, 2316, doi: 10.1029/2000JB000103.

Marra, F., R. Azzara, F. Bellucci, A. Caserta, G. Cultrera, G. Mele, B. Palombo, A. Rovelli and E. BosCHI (2000): Large amplification of ground motion at rock sites within a fault zone in Nocera Umbra (Central Italy), J. Seism., 4, 543-554.

Meghraoui, M., V. Bosi and T. CAmelbeeck (1999): Fault fragment control in the 1997 Umbria-Marche, central Italy, earthquake sequence, Geophys. Res. Lett., 26 (8), 1069-1072.

Messina, P., F. Galadini, P. Galli and A. Sposato (2002): Quaternary basin evolution and present tectonic regime in the area of the 1997-1998 Umbria-Marche seismic sequence (central Italy), Geomorph., 42, 97-116.

Moro, M., M. Saroli, S. SAlvi, S. and F. Doumaz (2007): The relationship between seismic deformation and deep seated gravitational movements during the 1997 Umbria-Marche (Central Italy) earthquakes, Geomorph., doi: 10.1016/j.geomorph.2006.12.013.

Pantosti, D, P.M. De Martini, P. Galli, F. Galadini, P. Messina, M. Moro and A. Sposato (2000): Studi paleosismologici attraverso la rottura superficiale prodotta dal terremoto del 14 ottobre 1997 (Umbria-Marche), GNGTS, Atti del $18^{\circ}$ Convegno Nazionale, Roma 1999.

Salvi, S., S. Stramondo, M. Cocco, M. Tesauro, I. HunStad, M. Anzidei, P. Briole, P. Baldi, E. Sansosti, G. Fornaro, R. Lanari, F. Doumaz, A. Pesci and A. GaLVANI (2000): Modeling of coseismic displacements resulting from SAR interferometry and GPS measurements during the 1997 Umbria-Marche seismic sequenze, J. Seism., 4, 479-499.

Stramondo, S., M. Tesauro, P. Briole, E. Sansosti, S. Salvi, R. Lanari, M. Anzidei, P. Baldi, G. Fornaro, A. Avallone, M.F. Buongionno, G. Franceschetti and E. Boschi (1999): The September 26, 1997 Colfiorito, Italy, earthquakes: modeled coseismic surface displacement for SAR interferometry and GPS, Geophys. Res. Lett., 26 (7), 883-886.

Tondi, E., G. CEllo and S. MAzzoli (1997): Strutture sismogenetiche in Appennino Centrale: potenziale sismico, analisi frattale e processi di crescita, Il Quaternario, 10 (2), 409-414.

VitA-FInZI, C. and G. C. P. KING (1985): The seismicity, geomorphology and structural evolution of the Corinth area of Greece, Philosophical Transaction of Royal Society of London, A314, 379-407.

Vittori, E., G. Deiana, E. Esposito, L. Ferreli, L. Marchigiani, G. Mastrolorenzo, A.M. Michetti, S. Porfido, L. Serva, A.L. Simonelli and E. Tondi (2000): Ground effects and surface faulting in the September-October 1997 Umbria-Marche (Central Italy) seismic sequence, J. Geodyn., 29, 535-564.

Wells, D.L. and K.J. CopPERSMITH (1994): Updated empirical relationships among magnitude, rupture length, rupture area, and surface displacement, Bull. Seismol. Soc. Am., 84, 974-1003.

WESTAWAY, R. and J. JACKSON (1987): The earthquake of 1980 November 23 in Campania-Basilicata (Southern Italy), Geophys. J. R. astr. Soc., 90, 375-443. 